International Journal of Agriculture and Environmental Research

ISSN: 2455-6939

Volume: 07, Issue: 06 "November-December 2021"

\title{
EFFECTS OF DIFFERENT SOURCES OF BORON IN SOIL
}

\author{
${ }^{1 *}$ Tiago Cesar Divino da Silva, ${ }^{2}$ Kleso Silva Franco Junior, \\ ${ }^{3}$ Giselle Prado Brigante, ${ }^{2}$ Marcio de Souza Dias
}

${ }^{1}$ Department of Fitotecnia, CESEP Machado MG, Brazil.

ORCiD: 0000-0003-3746-244

${ }^{2}$ Department of Fitotecnia, CESEP Machado MG, Brazil.

ORCiD: 0000-0002-6807-8889

${ }^{3}$ Department of Fitotecnia, CESEP Machado MG, Brazil.

ORCiD: 0000-0002-0952-0075

${ }^{4}$ Secretary of education, SEE-MG Serrania MG, Brazil.

ORCiD: 0000-0001-8367-1341

*Corresponding author

DOI: https://doi.org/10.51193/IJAER.2021.7603

Received: 20 Nov. 2021 / Accepted: 30 Nov. 2021 / Published: 02 Dec. 2021

\begin{abstract}
Brazil has a great variety and characteristics of soil, which is due to the size and continental proportions of the country. Oxisols, argisols and neosoils predominate. These soils are characterized by their predominant characteristic of depth and highly weathered, thus bringing the characteristics of being acidic, with low natural fertility and, in some cases, high aluminum saturation in the profile. With these premises, the present study aimed to evaluate different sources of boron applied to the soil to overcome these deficiencies found. The study was conducted in the city of Campestre and used as boron sources: boric acid complexed with monoethanolamine (treatment 1), boric acid complexed with organic protein (treatment 2), ulexite (treatment 3), and boric acid (treatment 4), in addition, there was also the control without the application of boron (treatment 5) and as dosage was applied $5 \mathrm{~kg}$ per hectare of boron. It was conducted in randomized blocks with five replications and after 120 days of application, soil samples were collected from each treatment and submitted for analysis in the laboratory and
\end{abstract}


submitted to Scott-Knott averages with 5\% probability. It was concluded that the application of Boron complexed with Monoethanolamine resulted in better levels of nutrient availability to the soil, but all sources of B used in the research promoted increments of the content of this element in the soil.

Keywords: Boron sources, complexed boron, availability boron.

\section{INTRODUCTION}

In Brazil, there is a great diversity of soils resulting from the continental extension of the country, where it is possible to observe and observe a great diversity of soil environments and factors for soil formation [5]

It is common to find mainly Latosols, Argisols and Neosols, which together are distributed in more than $70 \%$ of the Brazilian territory, being mainly $58 \%$ by Latosols and Argisols, characterized as deep soils, because they have a high weathering, besides being highly acidic, possessing a low natural fertility and in some cases also containing a high aluminum saturation [5]

Boron (B) is a chemical element present in soils and plants, being considered as essential for the maintenance and development of some plant activities, it is defined as a micronutrient and usually found in few concentrations [21]

According to PRADO [19], B plays numerous roles in plant life, whether acting in cell wall synthesis, or cell elongation, or in membrane integrity or in carbohydrate transport and reproductive growth.

Boron is a nutrient whose transport is unidirectional in the xylem, that is, the plant does not redistribute it, and in the phloem $B$ is practically immobile, which causes the appearance of deficiency in younger organs and in the growth regions [23], in general, a constant supply of this nutrient is required for the maintenance and development of the plant [8]. It is worth mentioning that $\mathrm{B}$ is a nutrient where there is a small difference between deficiency and toxicity.

Commercially, there are several products designed to provide nutrients to plants, as well as micronutrient B in particular. One of the main forms of availability of B is in the form of Boric Acid (H3BO3), which manages to provide at least $17 \%$ of boron, while Ulexite (B5O9CaNa $8 \mathrm{H} 2 \mathrm{O}$ ) can provide $10 \% \mathrm{~B}$.

However, there are commercial products that offer B and with a liquid application route, which in this case is Boron Monoethanolamine is a solution of Boric Acid complexed with Monoethanolamine, ensuring an application of the nutrient and practicality, since this compound 
International Journal of Agriculture and Environmental Research

ISSN: 2455-6939

Volume: 07, Issue: 06 "November-December 2021"

can be made available B through spray, guaranteeing an availability of $10 \%$ of B, another product that stands out for spray application is Boric Acid Complex with Organic Protein, which also guarantees a nutrient availability of $10 \%$.

Today, fertilization is concentrated in two lines, being them via soil that uses mainly solid compounds and also via foliar, which is exclusively carried out by an aqueous medium.

In soil, B is available mainly as boric acid (H3BO3) or borate, and it can be strongly adsorbed to the organic and inorganic fraction $[3,17]$.

In general, only undissociated soluble B is available to plants, which corresponds to only $10 \%$ of the total B in the soil $[11,18]$.

From the sources of B to the soil, tourmaline is the main source, however, for plants the main source of $\mathrm{B}$ comes from the mineralization of the organic matter that makes the nutrient available. Thus, there is a relationship between the content of organic matter and the amount of B [12], which in turn, soils that have reduced levels of organic matter and factors that reduce its mineralization, will predispose to a lack of B to culture employed [11].

Soil $\mathrm{pH}$ causes changes in the behavior and availability of $\mathrm{B}$, and in soils with low $\mathrm{pH}$, it will be found predominantly in the form of inseparable boric acid and with priority release to root absorption sites through mass flow. It is important to emphasize that soil $\mathrm{pH}$ is one of the main factors influencing nutrient availability, as it increases adsorption as the alkalinity of the medium increases $[10,17]$.

Depending on the availability of B, the absorption of boric acid by the roots can be carried out by three different molecular mechanisms: (i) passive diffusion through the lipid bilayer; (ii) transport facilitated by large intrinsic protein channels (MIP); and (iii) by an energy-dependent high affinity of the transport system induced in response to the low supply of B, which is mediated by BOR transporters $([5,24]$.

According to Taiz et al. [23], B is considered an element that has properties of both metals and non-metals (metalloids), which favors its transport to the roots by mass flow and enters cells via aquaporin-type channels, until a balance between the element levels in the roots and in the solution.

For Malavolta \& Kliemann [12] and Alves et al. [1], foliar application consists of a supply of nutrients by spraying the aerial parts of the plants, mainly on the leaves, because when the nutrient is deposited on the leaf, its absorption can occur in two ways (through the entry of the nutrient into the plant through diffusion or through the simplast with energy expenditure). 
With these premises, the present study aims to evaluate the different sources of boron applied to the soil and the availability after application of this nutrient.

\section{MATERIAL AND METHODS}

The study was conducted in a gleba that was fallow in the municipality of Campestre, located in the south of the state of Minas Gerais, at the coordinates: Latitude $21^{\circ} 42^{\prime} 10^{\prime \prime}$ South and Longitude: $46^{\circ} 07^{\prime} 48^{\prime \prime}$ West, at an altitude of approximately 1100 meters above sea level. The characteristic climate of the region is the $\mathrm{Cwb}$, that is, warm and temperate, and in winter it has a lower rainfall rate than in summer, and in the municipality temperatures have an annual average around $19^{\circ} \mathrm{C}$ with the accumulated historical average of $1,609 \mathrm{~mm}$ of precipitation [6]. For the application of the study, soil preparation was carried out in March 2021 with the plowing and grading of the area, in addition, a soil sample collection was carried out in the $0-20 \mathrm{~cm}$ layer with the aid of a Dutch trade, the samples were collected and then analyzed in the laboratory to verify the nutrient contents in the soil, the results are expressed in table 1.

Table 1: Result of initial soil analysis at the depth of 0-20 cm, Campestre/MG (2021).

\begin{tabular}{|c|c|c|c|c|c|c|c|c|c|c|}
\hline \multicolumn{2}{|c|}{ pH } & \multirow{2}{*}{\multicolumn{2}{|c|}{$\begin{array}{c}\text { Prem } \\
(\mathrm{mg} / \mathrm{kg})\end{array}$}} & $\mathbf{P}$ & \multirow{2}{*}{\multicolumn{2}{|c|}{$\frac{\mathbf{K}}{\left.m g / d m^{3}\right)}$}} & \multicolumn{2}{|c|}{$\mathbf{V}$} & \multirow[t]{2}{*}{$\mathbf{m}$} & \multirow{2}{*}{$\begin{array}{c}\text { MO } \\
(d a g / K g)\end{array}$} \\
\hline$\left(\mathrm{H}_{2} \mathrm{O}\right)$ & $\left(\mathrm{CaCl}_{2}\right)$ & & & & & & & (\%) & & \\
\hline 5,20 & 4,60 & & & 2,74 & & & & & 13,12 & 2,87 \\
\hline $\mathbf{C a}$ & Mg & Al & $\mathbf{H}+\mathbf{A l}$ & $\mathbf{T}$ & Zn & $\mathbf{F e}$ & Mn & $\mathbf{C u}$ & B & S \\
\hline & & $l c / d m$ & & & & & & $\left(m^{3}\right)$ & & \\
\hline 1,67 & 0,64 & 0,36 & 5,50 & 7,89 & 2,20 & 45,70 & 10,60 & 0,90 & 0,30 & 1,10 \\
\hline
\end{tabular}

Source: The author.

The experiment was conducted with five treatments: treatment 1 - boric acid complexed with monoethanolamine $(10 \% \mathrm{~B})$; treatment 2 - boric acid complexed with organic protein $(10 \% \mathrm{~B})$; treatment 3 - ulexita $(10 \% \mathrm{~B})$; treatment 4 - boric acid $(17 \% \mathrm{~B})$; treatment 5 - control $(0 \% \mathrm{~B})$. The application of each dosage of the treatments was $5 \mathrm{~kg}$ per hectare of $\mathrm{B}$. The study was conducted in the methodology of randomized blocks, containing five replicates per treatment, totaling 25 experimental plots of $1 \mathrm{~m}^{2}$ each and being with a distance of $1 \mathrm{~m}$ in all directions, as represented by Figure 1. 
Figure 1.

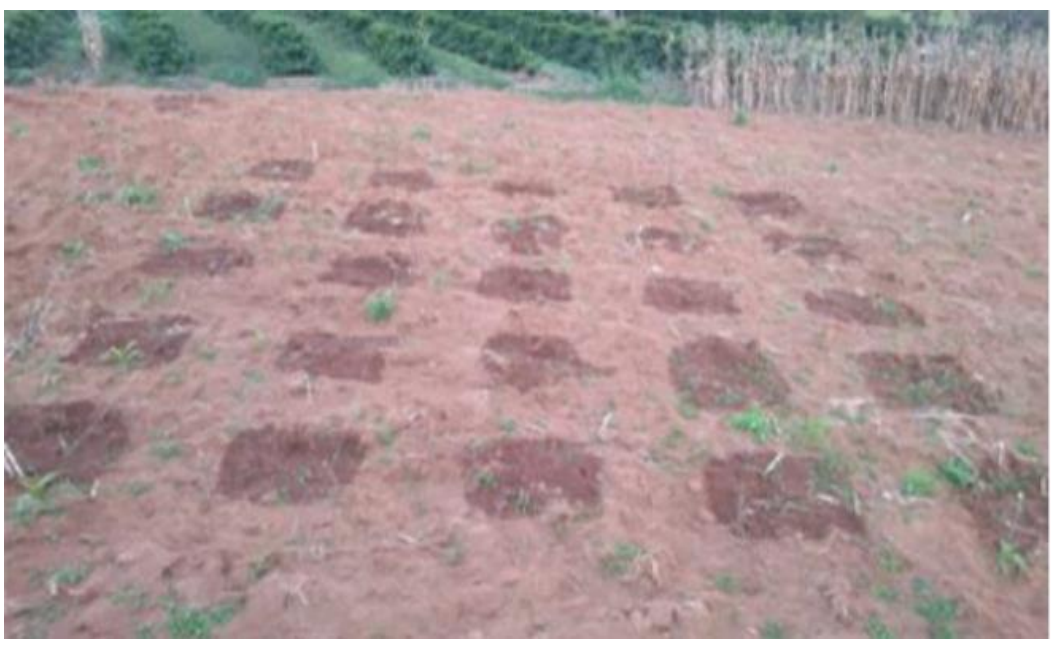

Source: The author.

The application of treatments was done manually, where each plot was marked with stakes and plates for proper identification.

After four months of treatment applications, sampling was carried out in the $0-20 \mathrm{~cm}$ layers with the aid of a Dutch auger, 20 subsamples were collected per plot to compose the sample of each plot, later sent for analysis in the laboratory to verification of the concentration of B in the soil.

The B concentration results were tabulated in electronic spreadsheets and later submitted to analysis of variance and comparisons of means were made by the Scott-Knott test with 5\% probability using the SISVAR @ software [9].

\section{RESULTS AND DISCUSSION}

After 120 days of application of treatments via soil, soil samples were collected in the 0 to $20 \mathrm{~cm}$ layer and in sequences submitted to soil analysis to measure the availability of B in relation to the treatments. Then, the data obtained were subjected to statistical analysis of variance, which evidenced the existence of significance $(\mathrm{F}>0.05)$.

Where treatments, Boric Acid complexed with Monoethanolamine, provided the highest levels of B, followed by Boric Acid complexed with Organic Protein, Ulexite, and Boric Acid.

Regarding the application of B sources at a dosage of $5 \mathrm{Kg} / \mathrm{ha}-1$, all sources of variation showed an increase in content compared to the control, which can be observed as shown in table 2 . 
As mentioned, the results from the treatment areas were superior to the control area that did not receive the micronutrient application.

Boric Acid complexed with Monoethanolamine was the result with the highest content and availability in the soil. Followed as the second best availability by Boric Acid complexed with Organic Protein and Ulexite, the latter two did not show any statistical difference between them.

Table 2: Available boron averages in the 0-20 cm layer.

\begin{tabular}{lrl}
\hline \multicolumn{1}{c}{ Fonte } & $\mathbf{B}\left(\mathbf{m g} / \mathbf{d m}^{\mathbf{3}}\right)$ & \\
\hline Boric Acid complexed with Organic Protein & 0,76 & B \\
Boric Acid complexed with Monoethanolamine & 1,02 & A \\
Boric Acid & 0,54 & C \\
Ulexite & 0,68 & B \\
Control & 0,32 & D \\
\hline
\end{tabular}

*Means followed by the same letters in the column do not differ statistically by the Scott-Knott test with 5\% probability. Source: The author.

The lowest result available in this case was that of the control, which was expected because it had no interference from the application of treatment, thus having a significant level already available in the soil. And, within the sources of variation (treatments), Boric Acid without having a complex has shown to have lower availability of this micronutrient in the soil.

The study showed a statistical difference between treatments, mainly for those that had boric acid and complexed to monoethanolamine, which diverges predominantly from that observed by Bologna [4], in which, when studying different boron sources, no different characteristics were noticed between them. at different dosages of micronutrient per kg.ha-1. However, the author points out that with the increase in the availability and application of boron to the soil, there is an increase in the availability of the nutrient in the soil.

In relation to Ulexite, it has a great particularity with regard to absorption, according to the report by APROSOJA [2], when the soil has high moisture content, the solubility of the nutrient entering the soil solution is greater and this provides better absorption and use by the installed cultures. As a convenience to this, it can also end up generating the possibility of leaching the nutrient to deeper layers, depending on the moisture content in which the soil is found.

Regarding this, by looking at table 3 , we can classify and interpret the availability of B in the soil. In relation to the averages observed, the control obtained a level considered low. 
International Journal of Agriculture and Environmental Research

ISSN: 2455-6939

Volume: 07, Issue: 06 "November-December 2021"

Table 3: AGEITEC, 2020 - Classes of interpretation of the availability of micronutrients in the soil, for the state of Minas Gerais.

\begin{tabular}{cccccc}
\hline \multirow{2}{*}{ Micronutrient } & \multicolumn{5}{c}{ Classification } \\
\cline { 2 - 6 } & Very Low & Low & Medium & Good & High \\
\hline Boric $\left(\mathbf{m g} / \mathbf{d m}^{\mathbf{3}}\right)$ & 0,15 & 0,16 a 0,35 & 0,36 a 0,60 & 0,61 a 0,9 & $>0,9$ \\
\hline Source: & Embrapa. & & Available & & at:
\end{tabular}

<https://www.agencia.cnptia.embrapa.br/gestor/feijao/arvore/CONTAG01_20_237200483743.html>.

Adaptation: The author.

The treatments can be classified as: Boric Acid Complex with Organic Protein - GOOD; Boric Acid Complexed with Monoethanolamine - HIGH; Boric Acid - MEDIUM; Ulexite - GOOD.

\section{CONCLUSION}

It was concluded that the application of Boron complexed with Monoethanolamine resulted in better levels of nutrient availability to the soil, but all sources of B used in the research promoted increments of the content of this element in the soil.

\section{REFERENCES}

[1] ALVES, A. U. et al. Absorção e mobilidade do boro em plantas de repolho e de couveflor. 2009.

[2] ASSOCIAÇÃO DOS PRODUTORES DE SOJA E MILHO DO ESTADO DE MATO GROSSO (Mato Grosso); FUNDAÇÃO DE APOIO À PESQUISA AGROPECUÁRIA DE MATO GROSSO (Mato Grosso). Avaliação de doses de boro e seus residuais para a cultura da soja. 2017. 18 p. Relatório Técnico Final - Nova Mutum - MT, 2017. Disponível em: http://www.aprosoja.com.br/storage/site/files/RF-Residual-de-boro.pdf. Acesso em: 11 nov. 2021.

[3] BARROS, N. F.; NOVAIS, R.F.; Eucalypt nutrition and ferlilizer regimes in Brazil. In: ATTIWILL, P. M. (Ed.) Nutrition of Eucalyptus. Collingwood: CSIRO, 1996. P. 335355.

[4] BOLOGNA, I. R. Adubação boratada em pomar de laranja pêra rio afetado pela clorose variegada dos citros. 2003. 89 p. Dissertação (Mestre em Agronomia) - ESALQ, Universidade de São Paulo, Piracicaba-SP, 2003. Disponível em: https://www.teses.usp.br/teses/disponiveis/11/11140/tde-01082003082909/publico/isabela. Acesso em: 11 nov. 2021.

[5] CAMACHO-CRISTÓBAL, J. J.; REXACH, J.; GONZÁLEZ-FONTES, A.; Boron in plants: Deficiency and toxicity. Journal of Integrative Plant Biology, v. 50, n. 10, 2008. p.1247- 1255 . 
International Journal of Agriculture and Environmental Research

ISSN: 2455-6939

Volume: 07, Issue: 06 "November-December 2021"

[6] CLIMATE-DATA.ORG. Clima Campestre. 2013. Disponível em: <https://pt.climatedata.org/america-do-sul/brasil/minas-gerais/poco-fundo-25005/>. Acesso em: 12 jul. 2020.

[7] EMBRAPA. Sistema brasileiro de classificação de solos. Brasília: [s. n.], 2020. Disponível em: https://www.embrapa.br/busca-de-publicacoes//publicacao/1107206/sistema-brasileiro-de-classificacao-de-solos. Acesso em: 13 out. 2021.

[8] FAQUIN, V. Nutrição mineral de plantas. 2005.

[9] FERREIRA, D.F. Sisvar: um guia dos seus procedimentos de comparações múltiplas Bootstrap. Ciência e Agrotecnologia; v.38-2p. 109-112,2014. Acesso em: 05 jun. 2021.

[10] FERREIRA, G. B. Interferência da matéria orgânica e ferro na dosagem de boro com Azometina-H e comparação de extratores para o boro disponível no solo. 1998. 98p. Dissertação (Mestrado em Agronomia) - Universidade Federal de Viçosa, Viçosa, 1998.

[11] LIMA, L. M. de S.; Revisão de Literatura. Absorção e translocação de boro em cafeeiro. Universidade Federal de Lavras, Minas Gerais. 2011.

[12] MALAVOLTA, E.; KLIEMANN, H.J. Desordens nutricionais no cerrado. Piracicaba: Potafos, 1985. 136p.

[13] MARSCHNER H. Mineral Nutrition of Higher Plants. 2nd edn. Academic Press, San Diego. pp. 379-396.

[14] NABLE R. O. examination of the resistance mechanism. Plant and Soil 112, 45-57,1988.

[15] NABLE, R. O.; BAÑUELOS, G. S.; PAULL, J. G.; Boron toxicity. Plant and soil. 193: $181-198,1997$.

[16] OERTLI, J. J. AND ROTH, J. A. Boron nutrition of sugar beet, cotton, and soybean. Agron. J. 61, 191-95, 1969.

[17] PAULA, T. de A. e; Doses, fontes e formas de aplicação de boro em floresta de eucalipto. Piracicaba, 2009.

[18] POWER, P.P., WOODS, W.G. The chemistry of boron and its speciation in plants. Plant Soil, v.193, p.1-13, 1997.

[19] PRADO, R.M. Nutrição de plantas. Jaboticabal. Ed. UNESP, 407p. 2008.

[20] ROESSNER U, PATTERSON JH, FORBES MG, FINCHER GB, LANGRIDGE P, BACIC A (2006). An investigation of boron toxicity in barley using metabolomics. Plant Physiol. 142, 1087- 1101.

[21] SANTOS, Enéias Rogger Freitas dos. Distribuição dos teores de boro em dois solos de diferentes texturas em função da aplicação localizada de ácido bórico. 2017. 23p. Trabalho de Conclusão de Curso (Graduação em Engenharia Florestal) - Universidade de Mato Grosso, Cuiabá-MT, 2017. 
International Journal of Agriculture and Environmental Research

ISSN: 2455-6939

Volume: 07, Issue: 06 "November-December 2021"

[22] STANGOULIS J.C.R.; REID R.J. Boron toxicity in plants and animals. In: GOLDBACH, H. B. et al. (Ed.) Boron in Plant and Animal Nutrition. Kluwer Academic, New York, USA. p. 227-240, 2002.

[23] TAIZ, L. et al.; Fisiologia e desenvolvimento vegetal. 6. ed. 2017.

[24] TANAKA, M.; FUJIWARA, T. Physiological roles and transport mechanisms of boron: perspectives from plants. Eur. J. Physiol. 456, 671- 677, 2008. 